\title{
The Partnering Society: Governmentality, Partnerships and Active Local Citizenship
}

\author{
Magnus Dahlstedt ${ }^{*}$
}

Department of Social and Welfare Studies, Linköping University, Norrkoping, Sweden

\begin{abstract}
In recent years, governing through partnerships has become more and more common and is today reflected in a range of policy areas. In the following article, governing through partnerships is analyzed in the context of Swedish politics and two policy areas (regional and urban policy) where the notion of partnership has had particularly large impact. Since each policy area deals with specific issues, the idea of partnership is framed in different ways. However, there are common features. In both of these policy areas, consensus and cooperation, adaptation and flexibility, entrepreneurship and development, bottom-up and local mobilization are political core values, albeit with a slightly different emphasis. With the idea of governing through partnerships, the political landscape is redrawn. The role of the State, for instance, is increasingly to leave room for various voluntary and independent actors and associations, to co-ordinate and interact, as a partner, among others, rather than directing society "from above".
\end{abstract}

Keywords: Partnership, governmentality, regional policy, urban policy.

\section{INTRODUCTION}

One of the themes that recurred consistently in the political debate around the turn of the millennium involved the idea that the solution to a long list of the more difficult challenges faced by today's society was to be found in collaboration among a variety of different actors. Polarisation and exclusion, unemployment and passivity, globalisation and competition, drugs and terrorism; in fact it is difficult to find any single issue where there isn't a view that what is needed is for different actors in society to join together, find common solutions and "pull together".

This type of governance is often referred to as partnering. Partnering is an umbrella term applied to a series of strategies that involve producing collaborations between different types of actors which extend beyond the sector-based divisions between government, market and civil society. An increasingly powerful ambition to govern society by means of the creation of such partnerships is today manifesting itself across a large number of areas of policy, including trade and industry and labour market policy, metropolitan and regional policy, education and crime policy.

Although the partnering concept itself may be a relatively recent addition to the Swedish political vocabulary, there has been a relatively long tradition of collaboration in both Swedish and European politics. The idea of collaboration between public sector agencies and various types of organisations was not least one of the most prominent features of the corporatist Swedish model, as symbolised by the institutionalised collaboration between the parties on the labour market in the form of employers and trade union organisations [1]. Mutual understanding was prioritised over conflict [2]. A series of interest groups were involved in the corporatist

*Address correspondence to this author at the Department of Social and Welfare Studies, Linköping University, Sweden; Tel: +46 11 363237; Fax: +4611363188; E-mail:magda@isv.liu.se collaboration and these were guaranteed a certain level of insight into and influence over central decision-making processes. At the same time they became an increasingly important part of the social democratic welfare project.

These corporatist collaborative arrangements disintegrated however during the 1980s and 1990s as the Swedish model became the focus of an increasing amount of criticism. This did not however mean that the politics of collaboration and agreement became a thing of the past. Rather, the 1990s witnessed something of a renaissance, albeit in a new form, in the increasingly widespread doctrine of partnering [3]. This emphasis on partnership is nothing unique to $1990 \mathrm{~s}$ Sweden, however. It is instead rather one part of a welfare policy transformation that has been taking place around the world since the 1980s and 1990s, in the context of which the exercise of power has been decentralised and organised in new ways, not least by involving many local community actors in the exercise of power in a variety of ways. The partnership concept became established first and foremost as a guiding principle in the political vocabulary of the EU during the $1990 \mathrm{~s}$, as an important element in the constant, ongoing "regeneration" of European welfare policy [4]. The ideal that has largely guided this "regeneration" has been that of "active citizenship". "Active citizenship focuses on whether and how people participate in all spheres of social and economic life, the chances and risks they face in trying to do so, and the extent to which they therefore feel that they belong to and have a fair say in the society in which they live" [5].

In this article, governance through partnering is illuminated by means of a focus on two different policy fields in Sweden around the turn of the millennium, fields in which the partnership idea has played a particularly central role. These are regional policy and urban policy. The presentation is organised around the following questions: Which contemporary problems and challenges are viewed as motivating governance through partnering? What solutions is this form of governance viewed as offering? How is the partnering in- 
tended to be staged and organised? The article begins with an analysis of how the partnering idea has manifested itself in the field of regional policy, and then moves on to the field of urban policy. Before taking a closer look at these policy fields, however, I first present a brief outline of the theoretical perspective on which the subsequent analysis is based.

\section{PARTNERSHIP AS GOVERNMENTALITY}

The expansion in governance through partnering is often said to be associated with a number of different, interwoven processes of change relating to the organisation and governance of society [6,7]. The first of these relates to a shift in the borders between the private and the public, with these borders having become increasingly porous. The state is said to no longer be able to deal with the issues and challenges of the day. There is an assumption that in order to be able to cope with contemporary challenges such as globalisation, the destruction of the environment, crime and terrorism, a powerful mobilisation is required of the resources that are available in different areas of society. Success is therefore said to require collaboration among a broad range of actors, all of whom must pull together. Through this public-private partnering, the borders between the public and private sectors are increasingly being transcended. A second, associated developmental process has witnessed the earlier, hierarchical government of society becoming increasingly supplemented and sometimes replaced by - more horizontal and networkbased forms of government, a shift from government to governance [8]. In contrast to earlier, corporatist forms of collaboration, today's partnerships are characterised by the fact that none of the involved parties is superior to any of the others. The state no longer dictates conditions, but rather functions as one partner among a number of others, such as firms and voluntary organisations for example. Thirdly, it is possible to discern a general trend towards the organisation of both private sector and central/local government activities in project form. As regards the ways in which partnerships are organised, these often assume project-like forms - they are restricted to dealing with a certain problem; they are delimited both organisationally and in time; the collaboration has a certain duration over time; the ambition is to conclude the collaboration as soon as the problem is resolved.

The current article proceeds from the theorizing around governmentality and governance in "advanced liberal" societies that has developed in the wake of the work of Michel Foucault [9-11]. Conceptually, the term itself, in combining the two words govern and mentality, captures more complex forms of governing than those usually referred to in a conventional understanding of "government". One crucial difference in relation to a conventional understanding is found in the way that those who constitute the "objects" of governance - citizens, peoples, city districts or regions - are not viewed as "passive" targets. Instead, governance in itself is rather said to form the "objects" or "targets". In this way, the governmentality concept may be said to capture the "mentality of government", i.e. how different conceptions and regimes of truth are related to political procedures and governmental techniques of various kinds [12]. For Foucault [13], governing does not originate in some self-evident fashion from the state apparatus as some kind of natural centre of power. Instead governance is rather comprised of a broad repertoire of technologies that operate across the entire social field.
In the "advanced liberal society", a form of citizenship has developed which is based on the twin principles of activation and responsibilization, with the responsibilities of citizens being emphasized in relation to their rights by means of a range of different techniques. In this context, the idea of "active citizenship" that has developed inter alia within the European Union is quite illustrative [14]. This idea is very clearly focused on the individual; it is ultimately individuals themselves who bear - and should bear - the responsibility for their own lives, in relation to both success and failure. "It is the human capacity to create and use knowledge effectively and intelligently, on a continually changing basis, that counts most. To develop this capacity to the full, people need to want and to be able to take their lives into their own hands - to become, in short, active citizens" [5]. In this sense, the ideal citizen emerges as a kind of entrepreneurial subject [15].

The ideal of active citizenship is staged by means of a series of different techniques - one of which is partnering. From the standpoint of a governmentality perspective, partnering may be viewed as a technique of governance comprising two closely related elements - on the one hand the creation of arenas for partnership, and on the other the moulding of the relevant partners. Firstly, partnering produces different institutional forms for collaboration between various actors which are based on specific rules $[7,16]$. These institutional forms may be anything from temporary, informal networks or fora for consultation and dialogue to more lasting, formal consultative and decision-making organs. The institutional forms complement, but in certain cases may also replace, existing organisational forms. Secondly, partnering produces contemplated partnering subjects with certain characteristics (such as an acceptance of responsibility, a willingness to listen and an aspiration to achieve consensus) [17, 18]. As Elina Palola, Taina Rintala and Annikki Savio note, "partnering society needs partnering citizens" [19]. Over time, partnering has become an increasingly important technique in the production of active citizenship. As partnering becomes an increasingly prominent form of governance, the role and areas of responsibility of the central government are transformed. The role of central government in contemporary "advanced liberal" societies is not to govern from above or to dictate the conditions for social development, but is rather that of being one partner among many, who together have the task of finding forms for partnering to continue and of determining the direction of future actions $[10,19,20]$.

On the basis of this theoretical perspective, the presentation now moves on to a more detailed examination of the arguments surrounding the phenomenon of partnering, and not least the way it relates to the idea of active citizenship, within two areas of policy, namely regional policy and urban policy, from the 1990 s onwards. The material analysed is first and foremost comprised of governmental inquiries and Government bills from the 1990s and first years of the $21^{\text {st }}$ century, drawn from the relevant areas of policy. As already stated, the analysis focuses firstly on the area of regional policy.

\section{REGIONAL POLICY}

Since the end of the 1980s, a growing number of academics, politicians and debaters have spoken of the increasing 
significance of the regional level. There has been talk of a "renaissance of the region". Within the European Union, people have spoken enthusiastically about the "Europe of the regions". And one of the more, and increasingly, important issues in European policy is that of how the regions are to succeed in producing economic growth. One of the central points of departure in both Swedish and European regional policy is the idea that regional development is no longer produced from above, but rather must grow from below. One key factor in this context is the establishment of regional development coalitions, or partnerships, which are consistently emphasised as one of the principal characteristics of successful growth regions. Thus during the 1990s, a new paradigm of regional development emerged in both Sweden and the $\mathrm{EU}$, focused on the three cornerstones of growth, a bottomup perspective and partnering [16].

The regional policy doctrine of the 1990s is essentially framed within a narrative focused on a radical shift in the conditions or rationality for policy activity. One very illustrative example of the nature of this narrative can be found in the Social Democrats' Government bill on regional policy from 1997, entitled Regional growth [21]. "Society is now faced with a revolution whose nature is every bit as fundamental as that witnessed when the agrarian society was squeezed out of existence by industrial society," the Government notes rather bombastically, "And there is much to suggest that in time, new developmental opportunities will be opening up for rural and sparsely populated areas". The revolutionary force that the Government primarily focuses on is the intensifying process of globalisation, which is said to involve major challenges for both the state and for society. Amongst other things, the forces of globalisation are restricting the room available for manoeuvre at the national level. "The fact that goods, services, capital and labour power can move freely over long distances restricts the opportunities for an independent national economic policy" [21]. According to the Government, the intense international competition that follows in the wake of globalisation requires regional interventions that meet the challenges of the day. The Government's guiding principles in this context are co-ordination, flexibility and decentralisation. "In order to achieve an increase in the efficiency of policy, certain changes are required, such as increased cross-sector co-ordination and flexibility in the use of the available means, and also a decentralisation of decision-making authority" [21].

The overarching goal of the sketched regional policy measures is growth. "In order to create good conditions for the production of goods and services that provide high incomes and high levels of welfare, policy must instead be focused on other measures that promote the capacity of firms to develop" [21]. The question of how growth is to be produced overshadows everything else, as is the case in many other regional policy documents from around the turn of the millennium. Looking back to an earlier point in history, the Government states that growth constitutes a prerequisite for a functioning welfare society. "The welfare society was built up during periods of favourable economic growth. In order to be able to distribute resources in a welfare society, these must first be created through growth" [21]. The Government concludes that growth thereby also constitutes a prerequisite for being able to build a welfare society that levels out various types of divisions within the country's borders, i.e. be- tween different regions. "The welfare system and the opportunities for creating equality between different regions require a high level of economic growth" [21].

The rapid pace of development witnessed over recent decades has quite simply produced a situation where the political map no longer reflects the reality of the situation. A new approach is required if individual regions - and by extension the whole of Sweden - are to be able to assert themselves in the context of increasingly intense international competition. This idea was put forward as early as 1997, in the Government bill Regional growth. The same idea is also conveyed in the final report from the governmental Inquiry into Organising for Regional Growth published in 2006, Improved competitiveness and employment throughout the country [22]. The report emphasises that established problem-formulations and solutions need to be replaced by new ideas that are more in line with the current situation. "In Sweden, initiatives for development and measures to resolve social problems often come from above," notes the Inquiry. "With the best of intentions, public sector actors, expert agencies, the county administrative boards, universities or others have assumed the task of identifying what should be done". The tone is recognisable from the critique that had been directed at the Swedish model and the posited, associated top-down control, since the end of the 1980s. "The topdown perspective creates passivity and powerlessness," the report continues, "and can easily lead to the spread of an attitude that 'somebody else' will resolve the problems" [22]. It is high time to replace the top-down perspective with a bottom-up approach.

According to the picture that emerges from documents relating to regional policy, the general trend of societal development appears more or less to necessitate an approach to working that proceeds from the principle of partnering. The Inquiry report Improved competitiveness and employment throughout the country states, for example that, "Developmental processes should be pursued in the form of partnerships." It continues, "Measures should be focused and rooted in political consultation. The process must proceed from the local environment where people and firms work, and must thus be conducted on a basis of a bottom-up perspective" [22]. According to the report, the only practicable way to achieve a sustainable regional policy is to base it on the formation of broad alliances that transcend traditional divisions between public and private, state, market and civil society. "In a process involving the political parties, associations, the business community, the social economy and others in partnership, the initial situation will be analysed and the question of which measures are most important to facilitate positive progress discussed" [22]. Partnering thereby functions as a technique for involving all the sectors in society in the apparatus of regional governance, even though it is far from all groups or interests that are involved as active partners. The idea of partnering is thus intimately related to that of safeguarding civil society from top-down governmental control, an idea which amongst other things has had a major impact in the contemporary debate on democratic regeneration [23].

The idea that the rapid pace of development in the increasingly globalised society has galloped away from a still static political superstructure is also found in another report from the same Inquiry, The organisation of regional devel- 
opment policy [24]. "Policy formulated in the traditional way no longer 'delivers'," the report states. The age in which we live is described as being characterised by a constantly increasing flexibility/complexity and - inversely - reduced governability. "This is related to a not insignificant extent to the increasing complexity of the social systems that policy is attempting to 'govern"'. According to the report, "the possibility of governing by means of public policy based on planning, command and control [has] diminished substantially over the past few decades" [24]. The idea of reduced governability, and the radically altered role of and conditions affecting policy also appears at this time within a range of other policy fields. The increased flexibility/complexity of society and its diminished governability are once again said to pave the way for forms of governance that transcend divisions between the public and private sectors. According to the Inquiry, the developmental trend is moving unconditionally towards a situation where "policy on its own is no longer able to provide the solutions to collective problems." Governance within "policy areas that deal with complex problems," including the area of regional development, are said to require "the collaboration of other spheres and actors such as firms and voluntary organisations ..." [24].

One important assumption found in the narrative of 1990s regional policy is that, in certain geographical locations, a certain "spirit" becomes established, with specific characteristics that may both stimulate and obstruct development and growth. "Certain regions of Sweden have an environment characterised by a spirit of enterprise whereas others are entrepreneurially weak," was how the Social Democratic Government put it in the 2001 regional policy Bill A policy for growth and vitality throughout the country [25]. "Entrepreneurial districts often have ... a long history of enterprise," the Government continues, "they have informal networks and civic spirit and attitudes that promote enterprise." The political scientist Robert D. Putnam [26] is a recurrent point of reference in this context, with his ideas about civic spirit and trust, social capital and institutional change.

Local assets in the form of social capital, culture and a climate of enterprise are important for the survival and competitiveness of firms and their capacity to evolve. [...] Social capital is built up locally and can thus not be purchased or moved. It is also based on the unique historical experiences and conditions of the region in question, which makes it difficult to imitate and produce from above [25].

In this context, the principal responsibility of central government comprises that of stimulating the emergence of the right kind of "spirit" or "climate" in various places. "Each region needs to be given better opportunities to stimulate development and the capacity to adapt on the basis of its often unique business culture" [21]. The argument proceeds from a kind of entrepreneurial ideology or entrepreneurial governmentality [16]. According to this ideology, the entrepreneur is viewed as the ideal member of society, an ideal citizen. The entrepreneur assumes the character of an almost Messianic figure, "a bearer of the light, and provider of the good", or a "flaming torch amidst the darkness of the grinding monotony of bureacratised undertaking" [27]. Entrepreneurial governmentality is based on a sharp distinction between the normal/desirable and the deviant/undesirable. The entrepreneur is full of initiative and is trusting and responsible, not passive, distrusting and indifferent. The entrepreneur seeks out the windows of opportunity, sees possibilities where others see limitations and difficulties. Society is said to be comprised of economic flows and of all the possible materials and energies that are contained within these flows. The development of capitalism requires creativity and innovation, constantly increasing efforts; it needs to constantly seek and conquer new domains or areas in order to generate increased growth.

The narrative of entrepreneurial spirit and enterprise culture is paradoxical however. On the one hand, entrepreneurship and enterprise are referred to as traditions and part of a deeply rooted cultural heritage, as if they were almost natural phenomena. They are strikingly often described in terms of "environment" and "climate", which gives them the aura of having a kind of material existence. The region is described as if it were a well-defined concrete unit and the local community as if it were a kind of homogeneous mass in need of mobilisation $[16,28]$. On the other hand, the narrative consistently refers to the possibility/necessity of creating new traditions and climates, of producing change and development. Those places that have not as yet developed a spirit of entrepreneurship and enterprise are not condemned to eternal underdevelopment. Given the use of offensive measures, these places too can develop a more enterprising climate $[6$, 29]. The essential challenge for central government in relation to regional governance is precisely that of providing the best possible conditions for the region or local community to itself create a "good developmental environment", as emphasised in the 2008 Budget Bill presented by the centre-right Alliance.

There is an intimate relationship between enterprise and regeneration. For the sake of growth and competitiveness, Sweden is therefore dependant on stimulating an improved climate for entrepreneurship, enterprise and innovation. The conditions for sustainable growth are increasingly related to the capacity for creativity and new thinking, which are fostered by openness, tolerance and diversity. The local, regional and national levels therefore need to create environments that retain and attract individuals who contribute to this and thus to competitiveness [30].

State governance is thus about "governing at a distance" rather than direction from the top down [10]. Collaboration is a precondition for the creation of such innovative environments. In order to succeed, it is necessary to mobilise all the resources that are available within the region or the local community. "A well developed dialogue, at the local, regional and national level, between the community and firms, constitutes an important part of a good developmental environment" [21]. In other words, successful partnering is an issue of vital importance not only for individual regions or local communities but for the country as a whole. "Sweden's economic growth will ... increasingly come to be affected by the capacity for collaboration and co-ordination in and between different regions" [21]. 
The vigorous, active local participation that is expected to follow from the consistent application of a bottom-up perspective on regional policy is viewed as valuable in several different respects. Running through the regional policy narrative from the 1990s onwards like an organising idea of some kind, we find an oftentimes explicitly stated notion that the mobilisation of all kinds of voluntary organisations and associations in local partnerships constitutes a way of creating a more vital local/regional democracy. A distinct example of this idea is found in the final report of the Rural Development Committee, See the countryside! [31]. The point of departure for the Committee's argument is once again Putnam's [26] ideas on social capital.

\begin{abstract}
In districts and contexts with strong, positive social cohesion and a wide range of activities in the areas of culture, the church, sport etc., trust and a positive atmosphere are produced between people which leads to the flourishing of what is termed social capital. Where this social capital is strong and well-developed, the work of change and development also goes much more smoothly and easily [31].
\end{abstract}

The areas where "social capital flourishes" are described as having a good democratic infrastructure. Trust, cohesion and active involvement are positive in themselves, but according to the Committee they also contribute to strengthening the quality and legitimacy of local decision making. "Active involvement at the local level provides the municipalities with a range of new proposals and perspectives that improve the quality of the acceptance of municipal solutions and decisions" [31]. Another aspect of the democratic value of voluntary work is related to the schooling in democracy that this type of work is claimed to provide. "Local voluntary work provides large numbers of people with experience of democratic work and decision making, which improves the level of cohesion within a municipality and facilitates the recruitment of active citizens by the parties working for the municipality" [31].

As we have seen, however, the primary value that regional policy focuses on is the economic one. "The voluntary work that takes place locally has a major practical and economic value for the municipality concerned" [31], states the Rural Development Committee in its final report. Not least, this voluntary work improves the level of social service. On the basis of amongst other things Putnam's ideas about social capital, the endeavours to bring about democratic regeneration are woven together with the idea of enterprise. "The local work conducted by various types of associations stimulates more people to assume some form of entrepreneurial role," notes the Committee, "whether this be in relation to the business, community or associations' sector" [31]. The talk of democracy is thus enveloped in the language of economics. Active involvement in the work of associations is amongst other things said to foster the local population in entrepreneurship, to generate substantial economic value and to generate valuable social capital. In that the mobilisation of the voluntary forces of the local community in local partnerships is assumed to produce a flourishing of the region's social capital, it is also assumed at one and the same time to promote both democratic and economic development. Democracy and enterprise are in practice viewed as one and the same thing. The one is a necessary condition for the otherand vice versa.

\section{URBAN POLICY}

The idea of partnering has not only been emphasised as a recipe for success in relation to rural areas and districts characterised by depopulation, however. During the 1990s, the parliamentary political parties were more or less in agreement that partnering also constituted a path to success for what are referred to as disadvantaged suburban environments. One prominent aspect of Swedish urban policy from the 1990s onwards has been the ambition to regenerate the urban landscape by means of involving the residents in the city planning process, particularly in "disadvantaged suburbs" [32].

If there was for a long time an idea of the city itself as a threatening environment (which broke down "natural" communities, atomised society, produced moral decay etc.), the corresponding feelings of concern are no longer directed at the city as such, but rather at specific locations in cities, and first and foremost those places that have come to be labelled "immigrant-dense", "disadvantaged suburbs" or "areas of exclusion" [33]. Just as a "spirit" characterised by enterprise, creativity, new ideas and development is said to emerge over time in certain places, other places (in both urban and rural environments) are said to be characterised by the emergence of a "culture of exclusion". In the context of the public debate, the environments referred to as "disadvantaged suburbs" are not uncommonly viewed as being characterised by passivity, isolation and benefit dependency [34]. In the climate surrounding the urban policy discussion that became established towards the end of the 1990s, the really major challenge was said to be that of transforming these environments into well-functioning neighbourhoods where the residents not only supported themselves, but were also actively involved in the life of the local community and identified with and were prepared to assume responsibility for this community [35]. As in the context of contemporary regional policy, urban policy is now also witnessing the emergence of an ideal of active local citizenship, captured in the use of the term "empowerment" [33].

Urban policy did not become established as a separate policy area until 1998, in connection with the Government bill Development and justice [36]. The bill is in several respects greatly influenced by the "spirit" of the period. One example of this is found in the way in which the Social Democratic Government consistently emphasises the use of partnering as a condition for being able to bring about lasting change in the country's metropolitan areas. In the bill, the Government underlines, amongst other things, the following:

\footnotetext{
Area-based programmes that combine local initiatives with external measures can strengthen the areas' social networks and provide fertile soil for achieving development and the creation of welfare. Such strategies require changes to the ways in which both the Government and other actors work. First and foremost, more clearly defined roles and areas of responsibility are required with a stronger emphasis on institutions based on partnership [36].
} 
According to the Government, a successful urban policy needed to be formulated "in a close dialogue with the residents" as well as "with other local actors such as e.g. the social insurance office, the health sector, the employment exchange and the local police service". It was important, noted the Government, that "all affected local actors stand behind the common goals so that they come to steer the efforts of each of the various actors in the city district concerned" [36]. The formulation "stand behind the common goals" in itself speaks volumes, in that it emphasises the principle of agreement, that the affected actors agree and pull together in the same direction. As we have seen, this principle has a long history in Swedish politics, but it recurs with a somewhat altered content in the idea of partnering that gained ground around the turn of the millennium in, amongst other areas, Swedish and European politics. In order to be able to collaborate in any way, what is first required is consensus around the conditions for this collaboration. This is an important point, and one that we will return to later in the article.

The bill presents the Metropolitan Initiative, a long term, large scale governmental project focused on 24 residential areas around the country. It is based on the signing of local "development contracts" with seven different metropolitan municipalities, namely Stockholm, Haninge, Huddinge, Södertälje, Göteborg, Malmö and Botkyrka. It involves spending two billion SEK over the course of a three-year period, distributed over a large number of local projects within the 24 areas concerned. In line with the idea that democracy is built from the "bottom up", the effort builds on an ambition to involve the residents in the relevant districts to the greatest possible extent in the process of defining problems/targets and of developing local packages of measures. Thus partnering constitutes the institutional form within which the project is planned and implemented.

\begin{abstract}
There are a large number of actors in the disadvantaged residential neighbourhoods who must work together in order to achieve the goals set out in the development contracts. These include among others various parts of the municipal administrations and local public sector agencies such as the labour exchanges. It is important that representatives of the local business community and of local clubs and associations are involved in both the formulation and the implementation of the plans. Similarly, it is very important that the county councils, and particularly the healthcare sector, participate in the local collaboration [36].
\end{abstract}

"Without the active involvement of the residents, we can only achieve superficial change," notes the Minister of Integration Ulrica Messing in a subsequent debate article published in the national broadsheet Svenska Dagbladet, and she emphasises once again the relationship between partnering and development [37]. The minister returns to this relationship in a parliamentary debate on the Government's new urban policy. She paints a rather contradictory picture of "metropolitan life". "Our metropolitan areas are swarming with life," she states.

But in the midst of these dynamics we also see problems that are particularly great specifically in our metropolitan areas. [...] It is in the metropolitan areas that the differences are greatest. Here there are gathered a flora of ethnicities, languages, traditions and cultures. It is here that the differences are most clear between those who have a place in society and those who do not [38].

Drawing support from the Government bill Development and justice, she emphasises that the Government's urban policy interventions are based on two premises: Firstly: "We have to reduce the differences between those in the absolutely worst situations and those in the very best". Secondly: "We have to do this on the basis of a bottom-up perspective" [38]. Proceeding from these two premises, she notes that local democracy, not least in the "disadvantaged" districts of metropolitan areas, should be given real opportunities to become revitalised, on their own terms, without central government governing the local community in detail and dictating its conditions.

The urban policy that we are now specifying is based on us looking seriously at our democracy from the bottom up, from the perspective in which democratic government originated, and which justifies its existence. [...] We are here providing more room for manoeuvre for local democracy in our metropolitan areas, and first and foremost in disadvantaged neighbourhoods. But it is not here in Parliament that local democracy will be created. It can only be created by we ourselves in the places where we live. Our task is that of providing the best possible opportunities for this to take place [38, emphasis added].

A common line of thought flows through this argument which ties together the concepts of partnering, a bottom-up perspective and democracy. Partnering is at heart presented as a technique that makes it possible to strengthen local democracy, not least in "disadvantaged neighbourhoods". The tone is recognisable not only from the contemporary debate on regional policy, which as we have just seen also clearly emphasises the application of a bottom-up perspective as a condition for a successful and sustainable regional policy line, but also from the late 1990s debate on the "regeneration" of local democracy [23]. According to this argument, democracy ought also to be viewed on the basis of a "bottom-up" perspective. For Messing, this was the perspective in which "democratic government originated, and which justifies its existence". The ambition is to extend "local democracy" and its "room for manoeuvre", particularly in "disadvantaged neighbourhoods". The decentralised approach is specified by means of the statement that local democracy is something created by "we ourselves" in "the places where we live". Messing thereby makes a distinction in relation to competence and responsibilities between central and local, between government and non-government. The conclusion is that the primary task of urban policy is that of providing the local community with the best possible opportunities to take care of itself.

In the Government bill Development and justice, partnering is viewed as the solution to a long list of different kinds of challenges. The notion of partnering is clearly visible, for 
example, in arguments about how the residents in "disadvantaged neighbourhoods" may be activated and responsibilised by involving them in various ways in the day to day administration of housing. Taking as its point of departure the regenerative work that had been underway for a time in a series of suburbs around the country, the Government states the following: "Among the housing companies that are active in disadvantaged areas, there is now a growing insight that the residents themselves constitute one of the most important tools for breaking down segregation" [36]. The Government sees before it the emergence of "new perspectives in which the tenants are seen as the collaborative partners of the property owners, instead of as passive rent-payers". The Government views the collected experiences of "increased tenant participation in disadvantaged neighbourhoods," in which the tenants have amongst other things "been given the opportunity to actively participate in the maintenance and cleaning of forecourts and stairwells" as good ones, and this for several different reasons.

The social benefits consist in amongst other things improvements to the atmosphere and to safety, strengthened social networks and a more positive view of one's own neighbourhood. Reduced vandalism and better care of the communal outdoor environment has given both economic and social benefits. Continuing to adapt their work in disadvantaged neighbourhoods so that the involvement of the residents can be utilised and developed constitutes an important task for housing firms. Increased involvement from residents also lays a good foundation for continued collaboration with the residents in areas other than the administration of housing [36].

The residents are not viewed as passive objects to be governed from above, but rather as active subjects. They are described as "the most important tools for breaking down segregation," as "collaborative partners instead of passive rent payers." The challenge consists in governing without disciplining, in inciting to activation and the assumption of responsibility. The partnering that the Government is talking about here does not constitute an institutional form for collaboration, involving defined frameworks and roles, but rather a more fluid technique of governance which at one and the same time transforms both person (the residents) and place (the neighbourhood). The Government's hope is that closer connections between housing companies and residents, but also among residents themselves, will produce a series of dynamic processes - social, economic and political - that in time may come to be driven by their own internal logic and to spread like rings on the water within the local community. In this way, the negative spiral of powerlessness that has been set in motion in the suburban environment can be transformed into a positive spiral of empowerment. Cleaning and maintenance are described as being partnering activities in a variety of different ways. The idea is on the whole much the same as that found in Putnam's [26] work. By socialising, the residents are said to bond with one another both socially and emotionally. Their social network becomes stronger. At the same time their sense of trust and solidarity is also strengthened, together with their view of themselves and the neighbourhood. Step by step, exclusion can be transformed into community. Step by step, the residents can be moulded into democratic citizens and the area into a vital local democracy [39].

Another area which the Government regards as suitable for the application of the idea of partnering is that of crime control. "A good local collaboration between amongst others schools and social services, as well as e.g. voluntary forces within the neighbourhoods, is necessary for the success of crime prevention work" [36]. The idea of involving the local community in crime control in various ways constitutes part of an international trend that increasingly gained ground in the Swedish crime policy debate in the years around the turn of the millennium [40]. The principle is once again that of working on the basis of a bottom-up perspective in order to make the best possible use of the residents' own experiences and desire to bring about change. Since when all is said and done it is the residents who are exposed to crime, the argument is that it is only natural to utilise precisely their own experiences and ideas in the work to prevent crime. "It is at the local level that the knowledge exists as to how best to affect the factors that constitute the very conditions for the commission of crime and how to influence the underlying circumstances that cause crime and insecurity among citizens" [36]. At the same time as the interfaces for collaboration and the number of actors involved increases, the techniques of power are multiplied - and secreted into the infrastructure of the local community [20].

It is not only the Social Democrats, however, who argue for partnering and a bottom-up perspective in the context of urban policy. Towards the end of the 1990s, partnering and a bottom-up perspective constitute a natural element in everyday political language across a large segment of the ideological spectrum. The Liberals, to take one example, frequently emphasise collaboration as a strategically important and dynamic local force, not least in "disadvantaged" suburban environments [41]. "In order for the people in a neighbourhood to have the chance to themselves create their community, it is necessary that the people themselves get the opportunity to release their creative energies," the party notes, for example, in an opposition bill from the end of the 1990s [42]. The party then lists a large number of actors and organisations: "Local business, clubs and associations, study associations, immigrant associations, churches, residents' groups and other local actors should be given the opportunity to change their everyday lives and build up local structures" [42]. The argument is strongly reminiscent of that which is at the same time being employed in government circles.

The Liberals view collaboration as an important element, amongst other things, in the work of crime prevention, particularly in "areas of social exclusion". Here too a parallel can be drawn to the urban policy program of the Social Democratic Government. In a debate article in the national broadsheet Dagens Nyheter, the party's leader, Lars Leijonborg, argues that the local community should be involved more clearly in the work to combat crime. "The level of insecurity in the Sweden of the socially excluded can be further reduced if those affected, in close collaboration with the police, themselves take on the task of recreating a safe environment" [43]. In order to go a step further than the Social Democrats had done in their Government bill Development and justice, Leijonborg proposes the establishment of special 
"security councils", in order "to mobilise the powers of civil society in the struggle against insecurity."

The Liberals in particular also provide an illustrative example of how regional and urban policy considerations around the turn of the millennium, across the political spectrum from right to left, come together in a common narrative on progress and how progress is produced. This can be seen not least in another opposition bill from the end of the 1990s, in which the party elucidates its fundamental position in relation to the question of partnering in the following way.

\begin{abstract}
Whether you live in a metropolitan suburb such as Alby or Hammarkullen, or in a sparsely populated district such as Idre or Dorotea, the foundations of policy must proceed from the capacity of the individual and the neighbourhood to mobilise their resources on the basis of their own situation. [...] The mobilisation of local resources is at least as important in the metropolitan areas in order to achieve progress and growth. It is therefore high time to see local mobilisation and the individual as providing developmental potential in metropolitan areas as well [44, emphasis added].
\end{abstract}

Basically, Idre and Hammarkullen, Dorotea and Alby are facing the same challenges when it comes to achieving progress and growth. The solution is once again to be found in the neighbourhood, irrespective of whether this is a metropolitan suburb or a rural community, "mobilising its resources" on the basis of its own circumstances.

\section{CONCLUSION}

The idea of partnering is a sign of the times. Partnering is today a guiding light across a range of different policy fields both in Sweden and a large number of other countries. In this article, I have focused on the way in which the idea of partnering became established in the everyday policy language of 1990s Sweden in two policy areas, regional and urban policy. Since each of these policy areas revolves around issues specific to its respective area of focus, the content assigned to partnering and the aspects that are emphasised vary somewhat - regional policy prioritises growth and urban policy prioritises a bottom-up perspective. In spite of this, the two policy areas have several common characteristics. Across these areas, there is a focus on mutual understanding and collaboration, adaptability and flexibility, entrepreneurship and progress, a bottom-up perspective and mobilisation, as key policy values, although the relative emphasis placed on them shifts somewhat from one policy area to another. In both policy areas, partnering constitutes an important part of the idea of an active local citizenship, an idea that cultivates active involvement and participation, taking initiative and mobilisation from the "bottom up", among a range of different local community actors.

The notion of partnership "clearly do a great deal of work, at once legitimating, multiplying and joining up governance ambits" [20] in our contemporaries. In the partnering society, new borders are established to define the "legitimate extent" of policy, with the role of policy and central government increasingly becoming that of leaving space for voluntary and independent actors and associations to collaborate, as one partner among others. In the partnering society, "there is no longer any need to make traditional distinctions, divisions and categorisations - for instance, between the public and the private or the economy and the social - but different processes and dimensions intertwine to an ever greater degree..." [19]. With partnering, decision making will come to be guided by new criteria and on the basis of new grounds of judgement. Growth, efficiency and progress emerge into the spotlight $[8,45]$. This does not mean that central government has abdicated its role or that it no longer has a role to play. Instead, the character of its function has changed. The role of central government in "advanced liberal" societies is more that of mobilising, co-ordinating and controlling partnering and more or less "self-regulating" subjects than it is that of "governing through society" [10], redistributing resources and regulating people's life opportunities by means of various socio-political interventions. This ongoing "activation" is not only directed at individuals, but also at collectives. Everything from individuals to families, associations, city districts and regions are being given more space, by themselves - and together, in partnership - to produce progress and determine their future. In this, the local community is also becoming a central arena for governance, in both metropolitan and rural areas. It was shown above that the local community in particular is being assigned a crucial significance in the policy areas that have been analysed. It is first and foremost here that the opportunities are deemed to exist to realise the idea of active citizenship based on trust and active involvement, empowerment and responsibility.

All partners participate as equals, even if they aren't all equal in practice. Partnering opens up for participation, but not necessarily for influence. Partnering is based on dialogue, but at the same time disagreements are viewed as a problem. Partnering cultivates democracy, but the cultivation of democracy can also function to exclude. Partnering highlights a number of dilemmas. In conclusion, I will try to illustrate a few of these dilemmas of partnering by focusing on two different phenomena (urban development and place marketing).

The first phenomenon is urban development. A number of researchers have described certain patterns in the implementation of the metropolitan policy interventions that were launched towards the end of the 1990s, which in several respects occurred in a way that directly contradicted the policy goal of strengthening local democracy $[35,46]$. Juan Velásquez [47] provides an illustrative example of this in a study of the regeneration work conducted in the multi-ethnic Stockholm suburb of Alby. Here, during the first years of the new millennium, what was referred to as a citizens' panel was introduced, a forum comprising municipal officials and twenty or so "activists" with close ties to the local community in Alby. Similar fora were established at the same time in a variety of locations around the country [48]. The panel in Alby was put together with the objective of, in line with the urban policy ambition of working on the basis of a bottom-up perspective, producing an improved dialogue between municipal officials and residents, in which proposals could be generated for measures that would contribute to the "regeneration" of Alby. In a variety of respects, however, the actions of the local officials in relation to the residents in fact obstructed the ambitions for participation and influence among the broader populous. One problem, which has also been noted in other contexts, was that the officials' choice of 
both the people and the issues that were to be included in the dialogue was both selective and non-representative [45]. The officials chose primarily to include individuals they already knew, with whom they had good contacts and whom they judged to be reliable partners. Oppositional voices and interpretations were filtered out of the agenda.

The citizens' panel is staged by means of a specific rationality of consultation, according to which a hierarchical relationship is created between officials and residents. One central element in this rationality is the way the officials constantly emphasise their own profession and its conditions, a kind of professional egocentrism. In the meeting with the residents, it is as a rule the officials, their "expertise" and their own view of the problems at issue that end up in the foreground, while the residents, their circumstances and ideas slip increasingly further down the agenda. In this way, the conditions necessary for an equal partnership, in which officials and residents can meet without one of the parties defining the framework for the dialogue, are undermined. The residents' degree of participation as active partners is greatly restricted. The citizens' panel appears for the most part to take the form of a confirmatory rather than an advisory partnership, in which the residents are moulded to fit the ideals and conventions on which the partnership is based. More than anything else, in this instance partnering becomes a way for the local administration to construct a "local will of the people", with no substantive popular representation. It actually means that "community can be understood more as a managerial process than a concept" [28].

Before the local community can be mobilised, it must first be constituted as "mobilisable" [12]. It must be created as a political subject. It must be delimited, defined and assigned specific characteristics and values - a fixed nature [9]. In this context, the Government bills and governmental inquiries that have been analysed in this article can be understood as constituting something more than "merely" the basis of political decisions and policy interventions of various kinds, namely as interventions that in themselves make governance possible, amongst other things by creating both the space for collaboration and collaborative subjects.

The events in Alby are far from unique. A similar gap between ambition (dialogue on equal terms) and practice (hierarchical consultation) has been described in a series of other studies of partnering interventions both in Sweden and elsewhere $[8,45]$. This leads into the second phenomenon that I will focus on, place marketing. In prevailing political climates it is becoming increasingly important to see to one's image and attractiveness, as has been noted not least in the area of Swedish regional policy since the 1990s [29]. In the context of the work of regeneration that is currently taking place in both urban and rural areas around the country, the list of policy priorities is topped by growth, entrepreneurship and competitiveness. These are also specifically the values that determine the framework for the type of participation and influence that partnering opens up for [17].

For both cities and regions, the really big challenge today consists in marketing oneself as "attractive", both to investors/businesses and to potential migrants to the area. Place marketing and place branding have also become established concepts far beyond academic circles - and are now something of an industry in their own right, with everything from special consultants and coaches to conferences, manuals and journals. In order to generate strategies, goals and future scenarios, all kinds of local forces are mobilised in partnerships of various kinds - vision groups, development coalitions etc. With partnering, you could say that local decision making is opened up at the same time as it is closed down [49]. Decision making is opened up to the participation of a large number of new actors, at the same time as "the possibilities for citizens to require accountability diminishes as responsibility becomes increasingly unclear and the issues become formulated as apolitical". The work of marketing the area requires unity, that all local forces are brought together and stand behind the trademark. This because the trademark has to be integrated and uncontested in order to acquire a high market value.

The point of departure for partnering is thus that decision making is first and foremost about the will to act, about quickly and efficiently arriving at a common approach, rather than being about influence, a conception of democracy that directly contradicts the ambitions of proceeding from a bottom-up perspective, intensified democracy and reciprocal dialogue that have repeatedly been emphasised in the debate on regional and metropolitan regeneration policy, for example, over the past decade. The active local citizenship that is cultivated in the context of contemporary Swedish and European policy is not least legitimised by reference to democratic regeneration. At the same time, ideological divisions and conflicts are viewed as a problem per se, as constituting a threat to progress and development, as something that should be avoided as far as possible $[2,16]$. "The dominant practice of local partnership - as supposed to its rhetoric enshrines elitist, neocorporatist or neopluralist principles, and excludes or marginalizes more radical egalitarian and solidaristic possibilities" [5]. Consensus on the conditions for partnership is viewed, in a kind of echo of the "spirit of consensus" associated with the Swedish model, as a prerequisite for partnering.

The ideal collaborating subject that is staged by means of these partnerships is consequently an active, responsible, pragmatic, but at the same time conflict-avoiding subject. This ideal subject is willing to engage in partnering on the conditions that apply for the partnership in question, conditions which are largely formed by the ideology of entrepreneurship. She strives to make the problem formulations and goals of the partnership her own - i.e. to pull together, not to call into question and destroy the framework of established conventions, prevailing definitions of problems and solutions. The politics of consensus did not die with the Swedish model. It lives on, amongst other things in the context of the ideal of an active local citizenship, albeit in a new form, in a new time.

\section{REFERENCES}

[1] Rothstein B, Bergström J. Korporativismens fall och den svenska modellens kris. Stockholm: SNS 1999.

[2] Lewin L. Bråka inte! Stockholm: SNS 2002.

[3] Forsberg P. Nya former för institutionaliserat samarbete mellan stat, arbete och kapital? In: Neergaard A, Stubbegaard Y, Eds. Politiskt inflytande. Lund: Studentlitteratur 2000; pp. 123-42.

[4] Geddes M. Tackling social exclusion in the European Union? Int J Urban Reg Res 2000; 24(4): 782-800.

[5] European Commission. A memorandum on lifelong learning. Brussels: Commission of the European Communities 2000; pp. 5, 7. 
[6] Gossas M. Kommunal samverkan och statlig nätverksstyrning. Stockholm: Institutet för framtidsforskning 2006.

[7] Mörth U, Sahlin-Andersson K. Partnerskap i samhällsförändringens centrum. In: Mörth U, Sahlin-Andersson K, Eds. Privatoffentliga partnerskap. Stockholm: SNS 2006; pp. 11-37.

[8] Elander I. Partnerships and urban governance. Int Soc Sci J 2002; 54(172): 191-204.

[9] Cruikshank B. The will to empower. Ithaca Cornell University Press 1999.

[10] Rose N. Powers of freedom. Cambridge: Cambridge University Press 1999.

[11] Ong A. Neoliberalism as exception. Durham: Duke University Press 2006.

[12] Petersson K. Mobilisering av gemenskapen. In: Arnstberg K-O, Ramberg I, Eds. I stadens utkant. Botkyrka: Mångkulturellt Centrum 1997; pp. 86-113.

[13] Foucault M. On governmentality. In: Burchell G, Gordon C, Miller P, Eds. The Foucault effect. Brighton: Harvester 1991; pp. 87-104.

[14] European Commission. Making a European area for lifelong learning a reality. Brussels: Commission of the European Communities 2001.

[15] Kelley P. The entrepreneurial self and "youth at-risk." J Youth Stud 2006; 9(1): 17-32.

[16] Syssner J. What kind of regionalism?. Frankfurt am Main: Peter Lang 2006.

[17] Raco M. Governmentality, subject-building, and the discourses and practices of devolution in the UK. Trans Institute $\mathrm{Br}$ Geographers 2003; 28(1): 75-95

[18] Raco M, Imrie R. Governmentality and rights and responsibilities in urban policy. Environ Plan A 2000; 32(12): 2187-204.

[19] Palola E, Rintala T, Savio A. From welfare states to partnering societies. Paper presented at The 2006 ESPnet Conference, Bremen 2006; pp. 8-9.

[20] Roselvink G, Craig D. The man and the partnering state. Research paper no. 13. Local Partnerships \& Governance, University of Auckland 2004; p. 8.

[21] Bill 1997/98:62. Regional tillväxt; pp.15-16, 65. [Retrieved on 2009 March 12]. Available from: www.regeringen.se

[22] SOU 2006:3. Stärkt konkurrenskraft och sysselsättning i hela landet. Governmental report; pp. 10-11. [Retrieved on 2009 March 12]. Available from: www.riksdagen.se

[23] Dahlstedt M. The politics of activation. Alternatives: Global, Local, Political 2008; 33(4): 481-504.

[24] SOU 2006:5. Organisering av regional utvecklingspolitik. Governmental report; pp. 42-43. [Retrieved on 2009 March 12]. Available from: www.riksdagen.se

[25] Bill 2001/02:4. En politik för tillväxt och livskraft i hela landet. pp. 67-69. [Retrieved on 2009 March 12]. Available from: www.regeringen.se

[26] Putnam RD. Making democracy work. Princeton: Princeton University Press 1992.
[27] Styrhe A. Ideology and the subjectification of the entrepreneurial self. Int J Manag Concepts Philos 2005; 1(2): 168-73.

[28] Schofield B. Partners in power. Sociology 2002; 36(3): 663-83.

[29] Heldt Cassel S. Platsmarknadsföring, regional image och jakten på attraktivitet. In: Andersson F, Ek R, Molina I, Eds. Regionalpolitikens geografi. Lund: Studentlitteratur 2008; pp. 161-81.

[30] Bill 2007/08:1. Budgetpropositionen för 2008; p. 39. [Retrieved on 2009 March 12]. Available from: www.regeringen.se

[31] SOU 2006:101. Se landsbygden! [Governmental report]; pp. 62-63. [Retrieved on 2009 March 12]. Available from: www.riksdagen.se

[32] Hosseini-Kaladjahi H. Stora fiskar äter fortfarande små fiskar. Tumba: Mångkulturellt Centrum 2002.

[33] Tedros A. Storstadsproblem. Gothenburg: School of Public Administration. PhD Thesis. Gothenburg University 2008.

[34] Dahlstedt M. Reserverad demokrati. Umeå: Boréa 2005.

[35] Urban S. Att ordna staden. Lund: Arkiv 2005.

[36] Bill 1997/98:165. Utveckling och rättvisa; pp. 45-77. [Retrieved on 2009 March 12]. Available from: www.regeringen.se

[37] Messing U. "Segregerade bör leda kampen mot utanförskap." Svenska Dagbladet 2000.

[38] Record 1998/99:23. Utveckling och rättvisa. [Retrieved on 2009 March 12]. Available from: www.riksdagen.se

[39] Rose N. Community, citizenship, and the third way. Am Behav Sci 2000; 43(9): 1395-411.

[40] Hörnqvist M. The organised nature of power. Department of Criminology. PhD Thesis. Stockholm University 2007.

[41] Dahlstedt M. Att ställa krav är att bry sig. In: Tesfahuney M, Dahlstedt M, Eds. Den bästa av världar?. Stockholm: Tankekraft 2008; pp. 194-221.

[42] Member's Bill 1998/99:Sf634. En liberal integrationspolitik [The Liberal Party]. [Retrieved on 2009 March 12]. Available from: www.riksdagen.se

[43] Leijonborg L. Färre poliser i sju av tio svenska problemområden. Dagens Nyheter 2005.

[44] Member's Bill 1997/98:Sf8. Med anledning av Prop. 1997/98:16 Sverige, framtiden och mångfalden [The Liberal Party]. [Retrieved on 2009 March 12]. Available from: www.riksdagen.se

[45] Geddes M. Partnership and the limits to local governance in England. Int J Urban Reg Res 2006; 30(1): 76-97.

[46] Edström N, Plisch E. En känsla av delaktighet. Tumba: Mångkulturellt Centrum 2005.

[47] Velásquez J. Förankring och dialog. Department of Cultural Geography. PhD Thesis. Stockholm University 2005.

[48] Svensson J. Kommunikation, medborgarskap och deltagardemokrati. Lund: Department of Sociology. PhD Thesis. Lund University 2008.

[49] Mukhtar-Landgren D. Entreprenörsstaden. In: Tesfahuney M, Dahlstedt M, Eds. Den bästa av världar?. Stockholm: Tankekraft 2008; pp. 222-47, p. 233. $\mathrm{nc} / 3.0 /$ ) which permits unrestricted, non-commercial use, distribution and reproduction in any medium, provided the work is properly cited. 